\title{
Józef Duda, Polskie dzieje czasu budowy i czasu chwały, Fundacja Pomocy Szkołom Polskim na Wschodzie im. Tade- usza Goniewicza, Lublin 2015, ss. 631
}

Autor dzieła jest znanym historykiem, jego dorobek naukowy odznacza się wszechstronnością i dotyczy szerokiego spektrum zagadnień obejmujących dzieje gospodarcze Europy i Polski oraz rozważania o charakterze metodologicznym i historiozoficznym związane z rozwojem cywilizacji europejskiej. Poza erudycją jego prace odznaczają się głębią i oryginalnością świetnym stylem, często też mają dyskusyjny i kontrowersyjny charakter. Zaznaczone tutaj cechy jego pisarstwa uwidoczniły się w pełni w niniejszej publikacji, do której napisania przystąpił w szczytowym okresie swej twórczości naukowej.

Podstawa materiałowa recenzowanej pracy Józefa Dudy, chociaż z konieczności ma charakter reprezentatywny, jest bogata, obejmuje bowiem ok. 500 pozycji bibliograficznych dotyczących polskiego i obcego piśmiennictwa historycznego na temat dziejów Polski, od pierwszych kronik po dzieła współczesne. W omawianej publikacji znalazły odzwierciedlenie, poczynając od XIX stulecia, klasyczne pozycje naszej historiografii: dzieła Lelewela, dziejopisów ze szkół historycznych: krakowskiej i warszawskiej Szymona Askanazego (Władysława Konopczyńskiego), historyków międzywojennych (Ludwika Kolankowskiego, Oskara Haleckiego), a także piszących w okresie po drugiej wojnie światowej, jak: Władysław Czapliński, Janusz Tazbir i przede wszystkim naukowy mistrz Autora Adam Kersten. W głównych sporachi polemikach dziejowych toczonych przezhistoryków polskich J. Duda wypowiedział się za optymistyczna, a nie pesymistyczną interpretacją dziejów ojczystych oraz za Polską Jagiellońską a nie Piastowską.

Znalazło to swe wyraziste odzwierciedlenie w konstrukcji dzieła. Jego pierwsza część, zatytułowana Piastowskie fundamenty państwa polskiego, to zaledwie jedna dziesiąta część tekstu, natomiast Polska Jagiellonów..., Obywatelska Rzeczpospolita wielu narodów... i Rzeczpospolita Sarmatów... stanowią pozostałą część opracowania. Są to bowiem, zgodnie z zasadniczą koncepcją książki i jej tytułem, dzieje "czasu chwały".

Wyraźne dysproporcje wystąpiły też w usytuowaniu poszczególnych kręgów tematycznych. Sprawy gospodarczo-społeczne, ustrojowe, a także dzieje kultury stanowią stosunkowo niewielki procent narracji. Dominuje w niej, i to w sposób zdecydowany, problematyka polityczna dotyczą- 
ca zarówno spraw wewnętrznych, jak i zagranicznych, a więc dyplomacji i wojen. Nie jest to jednak tylko faktografia, a wręcz przeciwnie - rozważania te mają głęboki, analityczny charakter, uwzględniają różnorakie przyczyny i skutki wydarzeń, ukazują rolę osób biorących w nich udział, przede wszystkim władców, ale także i tych, którzy należeli do ówczesnych elit politycznych. Ich charakterystyki są pogłębione, a podejmowana przez nich działalność przedstawiona w sposób barwny i interesujący. W przedstawieniu tej problematyki Autor ujawnił w pełni swój talent pisarski. Jego potoczysta narracja składa się z dwóch zasadniczych warstw: opisującej i wyjaśniającej, a więc skłaniającej czytelnika do własnych refleksji, przemyśleń i wniosków, także krytycznych.

W swych zasadniczych rozważaniach J. Duda uzasadnia, że unia polsko-litewska była $\mathrm{w}$ dziejach Polski wydarzeniem przełomowym. Nie szczędzi więc pochwał dla jej głównych architektów - panów krakowskich, stanowiących ukształtowaną w czasach Kazimierza Wielkiego elitę polityczną. Wskazuje, iż pierwszym jakże ważnym osiągnięciem unii dwóch narodów było zwycięstwo nad zagrażającym ich bytowi zakonem krzyżackim. Dziejową natomiast rolę państwo jagiellońskie odegrało jako pomost między zachodem i wschodem Europy, szerząc tam katolicką cywilizację europejską i idee republikańskie. Co więcej, zdaniem Autora: „Idee wolności, równości i braterstwa, które przyświecały politycznemu narodowi Rzeczpospolitej, stały się niezmiernie ważne w Europie dopiero [...] w czasie Rewolucji Francuskiej, ale po raz pierwszy wypłynęły już w Rzeczpospolitej Obojga Narodów". Konieczny jest tu jednak komentarz. W rewolucyjnej Francji miały one dotyczyć wszystkich jej obywateli, w Rzeczypospolitej tylko szlachty, czyli ok. jednej dziesiątej ogółu społeczeństwa.

Uproszczeniem jest stanowisko J. Dudy utożsamiającego cywilizację europejską jedynie z religią katolicka, bowiem zarówno cywilizacja, jak i kultura europejska wiele czerpały z idei humanizmu oraz odrodzenia, a także z idei etycznych i społecznych powstałych w wyniku reformacji Kościołów protestanckich.

Rolę renesansu w Polsce Autor pomniejsza - według niego epoka ta „nie była w naszych dziejach szczególnie twórcza, ani rozległa przestrzennie, szybko przeminęła nie przenikając głęboko do bardzo licznego polskiego narodu politycznego, miała elitarny charakter" (s. 157). Opinię tę można uznać za dyskusyjna, natomiast stwierdzenie, iż „Mit Renesansu jako szczególnej epoki w dziejach Europy wyrósł z potrzeb liberalnych i antykatolickich kręgów intelektualnych XIX i XX w. jako przeciwstawie- 
nie obciążonemu nadmiernymi powiązaniami z wiarą katolicką średniowieczu" (s. 225) jest już wyraźnym argumentem o charakterze światopoglądowym.

Przedstawiając recepcję systemu kopernikowskiego w Europie, J. Duda zdezawuował dwóch jego słynnych wyznawców i obrońców: Galileusza i Giordana Bruna. Ten pierwszy był jego zdaniem człowiekiem apodyktycznym, nieznoszacym sprzeciwu i zachował się wobec inkwizycji prowokacyjnie, ten drugi to „awanturnik” (s. 233). Wydaje mi się jednak, że w tym wypadku w swej wielokrotnie zaznaczonej na kartach książki pasji polemicznej Autor przekroczył granicę.

Ukazana postać kmiecia z końca XV w., który w niedzielę, wybierając się do kościoła, zakładał zawsze odświętną sukmanę ozdobioną najczęściej złotym łańcuchem (s. 210), wpłynęła na jednostronne i wyidealizowane postrzeganie kwestii chłopskiej w Rzeczypospolitej. Tymczasem już w XVI, a szczególnie w XVII stuleciu wraz z rozwojem gospodarki folwarcznej i zwiększającym się obowiązkiem pańszczyźnianym oraz innymi formami ucisku ze strony dworu położenie chłopów uległo znacznemu pogorszeniu. Wynikało to m.in. z przywołanych przez Autora ślubów lwowskich Jana Kazimierza, zawierających jakże wymowny fragment przyrzeczeń króla, iż „będzie czynił starania po zwycięstwie, by lud polski od uciążliwości i ucisku wyrwać". Słowa te J. Duda uznał jedynie „za zawsze obecne i wyraźne nawoływanie katolików do miłosierdzia wobec bliskich, którzy znajdują się w gorszej sytuacji" (s. 502). Owo niedostrzeganie, a raczej zanegowanie istniejących między szlachtą a chłopami napięć i sprzeczności o charakterze społecznym doprowadziło go do stworzenia uproszczonego obrazu i posługiwania się sienkiewiczowską terminologią w opisie powstania Chmielnickiego na Ukrainie. Według niego uczestniczyli w nim obok kozaków: „czerń", „rezuni”, „czerń kozacka”. A byli to ciemiężeni przez kresowych latyfundystów chłopi. Tego rodzaju stanowisko J. Dudy budzi zdziwienie, zwłaszcza wobec coraz bardziej powszechnych i demonstrowanych przez młodych polskich badaczy poglądów nieodwołujących się do pryncypiów walki klasowej, a traktujących system poddańczo-pańszczyźniany jako jedną z form niewolnictwa.

Ostatnia część publikacji: Tożsamość Sarmaty Obywatela Rzeczypospolitej to pełna pasji i zasadnicza polemika Autora z krytycznym od czasów oświecenia w naszym piśmiennictwie obrazem sarmatyzmu, a także wielki pean na cześć Sarmaty Obywatela jako reprezentanta najbardziej dla tego okresu typowej i zdaniem J. Dudy jakże bogatej oraz godnej szacunku kultury narodowej. 
Jakkolwiek pełen podziwu dla demonstrowanych i tutaj umiejętności pisarskich Autora, nie zostałem jednak przez niego przekonany. Sarmatyzm utwierdzał bowiem szkodliwy dla państwa egoizm polityczny i społeczny szlachty oraz jej przekonanie o doskonałości i stałości istniejącego ustroju i porządku. Przyczynił się też do powstania wielu legend i mitów. Naczelnym z nich, zresztą wielokrotnie przypominanym przez J. Dudę, było powszechne przekonanie o Polsce jako przedmurzu chrześcijańskiej Europy. Wyrosło ono na kilkuwiekowej tradycji rzeczywistej walki z Turcją jaką Polska musiała toczyć w obronie swej niezawisłości i terytorium, a także $w$ związku z powiązaniami dynastycznymi i politycznymi sojuszami. Warna i Mochacz, Cecora i Chocim oraz Wiedeń zespoliły się w mit przedmurza, a szlachta wierzyła głęboko, iż Europa chrześcijańska, mająca Polsce tyle do zawdzięczenia, będzie zawsze o tym pamiętała. Owe złudne nadzieje, mimo ogromnych zagrożeń, jakie zawisły nad Rzecząpospolitą w XVIII stuleciu, utwierdziły się i trwały w następnym stuleciu - aż do epoki rozbiorów, kiedy to właśnie Austria, zapominając o 1683 r., jako pierwsza w 1772 r. zaczęła przyłączać graniczne obszary Rzeczypospolitej do swego terytorium.

Po lekturze tego jakże interesującego dzieła nasuwa się zasadnicze pytanie. Dlaczego Autor określił epokę jagiellońską i Rzeczpospolitą XVII w., co w tym wypadku budzi zresztą uzasadnione wątpliwości, „czasami chwały”, a nie np. potęgi czy wielkości. Przecież dzięki unii z Litwą w granicach państwa obojga narodów znalazł się ogromny obszar ziemi na wschodzie Europy, sięgający prawie Moskwy, liczący milion $\mathrm{km} \mathrm{kw}$.

Dla zespolenia tego terytorium w jeden organizm ani Polska, ani Litwa nie posiadały odpowiedniej liczby ludności i potencjału gospodarczego ani też silnej organizacji państwowej. Trudno też mówić o efektach podkreślanego przez Autora promieniowania na Wschodzie republikańskiego sarmatyzmu i religii katolickiej, kiedy w rosnącej w potęgę Moskwie Iwan Groźny zniweczył całkowicie aspiracje bojarów, a prawosławie, zyskawszy status religii państwowej, zasklepiło się w obliczu unii brzeskiej we wrogości wobec innych wyznań. A zatem w pojedynku zasadniczym na tym terytorium, jaki Rzeczpospolita toczyła z Moskwa, reprezentowane przez nią idee i wartości uległy, jak pisze Autor, „prymitywnej, dzikiej cywilizacji państwa moskiewskiego". Nie zdołała też Rzeczpospolita obronić w długotrwałych i zaciętych bojach, toczonych z Moskwą, Turcja, Szwecją i z wyodrębniającą się Ukrainą, owego ogromnego terytorium, w którego posiadanie weszła. W drugiej połowie XVII w. zmalało ono do 
700 tys. km kw. Potęga czy wielkość stały się snem, chwały nikt nam odebrać nie może. Dużo to czy mało?

Te, a także wiele innych przemyśleń i wniosków, z jednej strony aprobujących, z drugiej dyskusyjnych i polemicznych, jakie niesie ta wyrazista, oryginalna i świetnie napisana książka, świadczy o jej randze i wartości.

Wiestaw Śladkowski (Uniwersytet Marii Curie-Skłodowskiej) 